\title{
Benefits of the Undergraduate Teaching Assistant Experience in an Introductory Biology Laboratory Course and Other STEM Courses
}

\author{
Frank R. Castelli, Mitra Asgari, and Mark A. Sarvary \\ Cornell University, Investigative Biology Teaching Laboratory, Department of Neurobiology \\ and Behavior, Comstock Hall, Ithaca NY 14853 USA \\ (FRC5@cornell.edu; MA2254@cornell.edu; MAS245@cornell.edu)
}

\begin{abstract}
Undergraduate teaching assistants (UTAs) are known to provide benefits to the students they teach, but there have been few studies examining how UTAs themselves benefit from the experience and how the graduate teaching assistants (GTAs) that they assist benefit. We have developed and are continually improving a teaching assistant program for undergraduates in an inquiry-based introductory laboratory biology course that enrolls upwards of 400 students each semester. Each lab section of up to 18 students is led by a GTA laboratory instructor who is assisted by one UTA. UTAs also hold office hours. Our team of about 12 UTAs work closely with their GTA mentors and attend a bi-weekly pedagogical training meeting. We will discuss the benefits and challenges of this UTA program from multiple perspectives, partly measured through UTA surveys, GTA surveys, and student evaluations given throughout the semester. We will also present some results of a related educational research project examining how the benefits of the UTA experience in biology courses, including ours, compares and contrasts with those in other STEM disciplines including chemistry and physics.
\end{abstract}

Keywords: undergraduate teaching assistants, pedagogy training, tutors, discipline comparison

Link to Original Poster File: https://doi.org/10.37590/able.v41.poster61

\section{Mission, Review Process \& Disclaimer}

The Association for Biology Laboratory Education (ABLE) was founded in 1979 to promote information exchange among university and college educators actively concerned with teaching biology in a laboratory setting. The focus of ABLE is to improve the undergraduate biology laboratory experience by promoting the development and dissemination of interesting, innovative, and reliable laboratory exercises. For more information about ABLE, please visit http://www.ableweb.org/.

Advances in Biology Laboratory Education is the peer-reviewed publication of the conference of the Association for Biology Laboratory Education. Published articles and extended abstracts are evaluated and selected by a committee prior to presentation at the conference, peer-reviewed by participants at the conference, and edited by members of the ABLE Editorial Board. Published abstracts are evaluated and selected by a committee prior to presentation at the conference.

\section{Citing This Article}

Castelli FR, Asgari M, Sarvary MA. 2020. Benefits of the undergraduate teaching assistant experience in an introductory biology laboratory course and other STEM courses. Article $61 \mathrm{In}$ : McMahon K, editor. Advances in biology laboratory education. Volume 41. Publication of the 41st Conference of the Association for Biology Laboratory Education (ABLE). https://doi.org/10.37590/able.v41.abs61 
Compilation (C) 2020 by the Association for Biology Laboratory Education, ISBN 1-890444-17-0. All rights reserved. No part of this publication may be reproduced, stored in a retrieval system, or transmitted, in any form or by any means, electronic, mechanical, photocopying, recording, or otherwise, without the prior written permission of the copyright owner.

ABLE strongly encourages individuals to use the exercises in this volume in their teaching program. If this exercise is used solely at one's own institution with no intent for profit, it is excluded from the preceding copyright restriction, unless otherwise noted on the copyright notice of the individual chapter in this volume. Proper credit to this publication must be included in your laboratory outline for each use; a sample citation is given above. 